\title{
O Banco Mundial e a construção político-intelectual do "combate à pobreza"
}

\author{
João Márcio Mendes Pereira
}

\author{
Todo poder nos é dado para que o usemos, e não para \\ que o embrulhemos num guardanapo, evitando arriscá-lo. \\ Robert McNamara, discurso na reunião anual do \\ Conselho de Governadores do Banco Mundial em 30 de setembro de 1968
}

Criado em 1944 e em operação desde 1946, o Banco Mundial sempre explorou a sinergia entre empréstimos e pensamento econômico para ampliar a sua influência e institucionalizar a sua pauta de políticas em âmbito internacional. Em pesquisa recente, ${ }^{1}$ desenvolveu-se a hipótese de que o Banco Mundial age, desde as suas origens, ainda que de diferentes formas, como um ator político, intelectual e financeiro, e o faz devido à sua condição singular de emprestador, formulador de políticas, ator social e veiculador de ideias - produzidas pelo mainstream anglo-saxônico e disseminadas por ele ou produzidas por ele, em sintonia com o mainstream - sobre o que fazer, como fazer, quem deve fazer e para quem, em matéria de desenvolvimento capitalista.

Desde os anos 1950 o Banco figura no centro do debate internacional sobre desenvolvimento, do qual uma das principais dimensões é a redução da pobreza. Contudo, pouco se estudou como a sua atuação político-intelectual contribuiu para vincular desenvolvimento à superação da pobreza e instituir ambos os temas como objetos legítimos de pesquisa econômica e de políticas públicas.

Nesse sentido, propóe-se neste artigo uma história da ideia de "combate à pobreza" advogada pelo Banco. Para isso, remonta-se aos anos de McNamara na presidência do Banco, quando essa bandeira foi enxertada e entronizada na instituição, relacionando-a com as tensões da Guerra Fria, a revisão da política norte-americana de ajuda externa ao desenvolvimento e os debates no interior do mainstream econômico. Em seguida, discute-se o porquê do esvaziamento da ideia de "combate à pobreza" na agenda operacional do Banco durante a primeira metade dos anos oitenta, para depois analisar-se o seu retorno a partir de 1986-87, associado à governabilidade dos programas de ajustamento estrutural promovidos pelo Banco em conjunto com o Fundo Monetário Internacional. Na sequência, argumenta-se como o Banco Mundial se voltou para a neoliberalização da política social, prescrevendo e legitimando programas de aliviamento paliativo e focalizado da pobreza como instrumentos preferenciais de ação dos Estados nacionais no âmbito da "questão social". No conjunto, mostra-se a continuidade básica entre algumas premissas que orientavam as prescrições do Banco nos anos setenta e no início dos anos noventa, como a confiança no "efeito derrame" e uma visão de política social centrada em mínimos sociais.

\section{A expansão do Banco Mundial durante a gestão McNamara (1968-1981)}

A chegada de Robert McNamara, em abril de 1968, à presidência do Banco Mundial marcou profundamente a história da instituição. Antes de ocupar o cargo, McNamara havia estudado e lecionado na Harvard Business School, presidido a Ford Motor Company e integrado o conselho consultivo da Fundação Ford. Indicado para o cargo de Secretário de Defesa dos Estados Unidos por Kennedy em 1961 e mantido por Johnson, teve um papel de destaque na atuação dos EUA na guerra do Vietnã. Se, antes da sua chegada, o Banco era "quase um apêndice do Tesouro dos EUA", 2 com ele a instituição se aproximou mais da área política do que da área econômica do Estado norte-americano. 
Não por acaso, a marca mais forte da sua gestão era a conexão entre segurança e desenvolvimento. $\mathrm{O}$ reconhecimento do fracasso da via predominantemente militar seguida pelos EUA no Vietnã reforçou a ideia de que a "segurança" dos EUA dependia não apenas das armas, mas também da preservação da ordem política, a ser obtida, pensava-se, por meio de crescimento econômico, melhoria dos indicadores sociais básicos e redução da desigualdade socioeconômica. Num livro publicado pouco antes de assumir o novo emprego no Banco Mundial, McNamara ${ }^{3}$ afirmou que "a pobreza e a injustiça social podem pôr em perigo a segurança do país tanto quanto qualquer ameaça militar”. Para ele, a relação entre pobreza e instabilidade política era válida para qualquer sociedade marcada por desigualdades profundas.

Tendo em vista o processo mais amplo de alargamento da distância entre naçôes ricas e pobres no pós-guerra, McNamara considerava - seguindo a mesma linha de outros intelectuais do establishment norte-americano, como W. W. Rostow ${ }^{4}$ - que o "atraso" econômico de alguns países e as contradições da modernização capitalista em outros abriam as portas para a influência comunista:

Dada a relação existente entre a estagnação econômica e a incidência da violência, os anos que aguardam as naçōes situadas na parte meridional do globo afiguram-se lúgubres. Isso seria verdadeiro mesmo que não existisse qualquer ameaça de subversão de ordem comunista, como, evidentemente, existe. Tanto Moscou como Pequim (...) consideram o processo de modernização um ambiente ideal para a expansão do comunismo. ${ }^{5}$

A partir desse diagnóstico, o então Secretário de Defesa sintetizou o que consistiria na condição da manutenção da supremacia norte-americana no mundo:

Permanece o fato incontestável de nossa segurança estar diretamente ligada à segurança desse novo mundo em desenvolvimento (...). Numa sociedade que está se modernizando, segurança significa desenvolvimento (...). Sem desenvolvimento interno, pelo menos em grau mínimo, ordem e estabilidade são impossíveis. ${ }^{6}$

Desde o seu início, a gestão McNamara foi influenciada pelo impacto da guerra do Vietnã sobre a política externa estadunidense. À medida que se desmanchava o consenso bipartidário em relação à política externa, a política de contenção (containment) que havia moldado as ações norte-americanas desde 1947 foi sendo abandonada no final dos anos sessenta e início da década seguinte. A mesma onda erodiu as bases de apoio da assistência externa ao desenvolvimento no âmbito doméstico e encerrou a aquiescência congressual sobre assuntos externos. $\mathrm{O}$ corolário disso foi a ingerência cada vez maior do Congresso sobre decisões relativas à política externa bilateral e multilateral, o que incluía uma fiscalização mais detalhada acerca da participação dos EUA no Banco Mundial. ${ }^{7}$

A gestão McNamara operou nesse contexto e, em larga medida, o objetivo de consolidar o Banco como uma "agência de desenvolvimento" foi, em grande parte, uma resposta àquela situação. O governo norte-americano apoiou ativamente esse movimento. No final da década de sessenta e início da seguinte, cresceu a convicção em Washington de que era necessário aumentar a assistência multilateral em relação à ajuda bilateral. Assim, numa mensagem enviada ao Congresso em setembro de 1970, Nixon propôs uma reorganização ampla do programa de ajuda bilateral e um reforço à ajuda multilateral. Para o governo, os bancos multilaterais de desenvolvimento (BMDs) poderiam alavancar fundos para os países da periferia, importantes do ponto de vista geopolítico, sem desgastar ainda mais o apoio doméstico à assistência internacional. Além disso, a roupagem multilateral permitiria aos EUA despolitizar a assistência externa e evitar tensóes diretas com certos governos, como poderia ocorrer pela via bilateral. A ênfase na assistência multilateral também aliviaria os custos financeiros da política externa norte-americana, num contexto de dificuldades econômicas para os EUA. ${ }^{8}$ Por fim, a roupagem multilateral dos BMDs permitiria a Washington contornar as críticas internas à guerra do Vietnã e ao apoio dos EUA a golpes militares e regimes ditatoriais que se espalhavam pelo então chamado Terceiro Mundo.?

Em seu primeiro discurso como presidente, McNamara fez um balanço socioeconômico dos anos sessenta e chegou à conclusão de que a imagem final era "nitidamente desapontadora".${ }^{10}$ Em primeiro 
lugar, porque a desigualdade de renda no sistema internacional havia aumentado; em segundo lugar, porque a maior parte da população permanecia em condiçóes de pobreza, ${ }^{11}$ apesar do aumento das taxas de crescimento econômico em grande parte dos países da periferia. Essa avaliação implicava o reconhecimento de que o estilo de desenvolvimento capitalista dominante havia falhado e que o esperado "efeito derrame" não tinha ocorrido. ${ }^{12}$ Assim, para McNamara, já não era mais válido considerar que crescimento econômico necessariamente levava à redução da pobreza. Era preciso distingui-los analiticamente, o que abria espaço para que ambos pudessem ser abordados de maneira separada e direta. Por outro lado, McNamara se recusou a admitir que a redução da pobreza pudesse vir a expensas da promoção do crescimento, como afirmava a imensa maioria dos economistas do Banco naquela época, e durante toda a sua gestão insistiu na centralidade do crescimento econômico. ${ }^{13}$

Lançada para o quinquênio 1968-73, a orientação da redução "direta" da pobreza dava sequência a mudanças na composição setorial da carteira do Banco iniciadas pela gestão de George Woods (1963-68), porém numa escala muito maior. McNamara anunciou a agricultura (na verdade, a agropecuária), como o setor que teria a maior expansão dentro do portfolio, com a justificativa de que constituía "o fator-chave para o crescimento econômico na maioria dos países em desenvolvimento", ${ }^{14} \mathrm{da}$ qual viveriam dois terços da população daqueles países. ${ }^{15}$ Também passariam a ter mais importância na carteira do Banco os projetos da área "social" - tradicionalmente considerados não-produtivos, por não gerarem retornos econômicos imediatos em moeda forte - como educação, fornecimento de água potável, saneamento básico, nutrição, saúde primária, habitação urbana e planejamento familiar.

Além de câmbios na alocação setorial, McNamara determinou mudanças na destinação geográfica dos empréstimos. Os desembolsos para a Ásia deveriam ser intensificados - em particular, para dar conta do retorno da Indonésia como cliente do Banco após o golpe militar, apoiado pelos EUA, que levou Suharto ao poder ${ }^{16}$, mas os "alvos" prioritários seriam a África e a América Latina. ${ }^{17}$ A Tabela 1 compara a carteira de empréstimos do Banco durante a gestão McNamara e a anterior, desagregando os dados por grupos de países. A Tabela 2, em seguida, compara a fatia de cada setor na carteira do Banco no mesmo período. 
Tabela 1. Volume de empréstimos do Banco Mundial entre 1961-82. Milhões de dólares

\begin{tabular}{|c|c|c|c|c|c|c|}
\hline & \multicolumn{3}{|l|}{ Anos 1961-69 } & \multicolumn{3}{|c|}{ Anos 1969-82 (a) } \\
\hline $\begin{array}{c}\text { Faixa de } \\
\text { Renda }\end{array}$ & Países & $\begin{array}{l}\text { No de } \\
\text { clientes }\end{array}$ & Total & Países & $\begin{array}{l}\text { No de } \\
\text { clientes }\end{array}$ & Total \\
\hline Total & & 93 & 9.436 & & 114 & 90.421 \\
\hline $\begin{array}{l}\text { Renda } \\
\text { alta }\end{array}$ & $\begin{array}{l}\text { Japão, Taiwan, Espanha, Finlândia, } \\
\text { Nova Zelândia, Austrália, Itália, } \\
\text { Cingapura, Israel, África do Sul, } \\
\text { Dinamarca, Noruega, Islândia, } \\
\text { Irlanda, Grécia e Áustria }\end{array}$ & 16 & 1.659 & $\begin{array}{l}\text { Bahamas, Chipre, Finlândia, } \\
\text { Grécia, Islândia, Irlanda, Israel, } \\
\text { Nova Zelândia, Cingapura, } \\
\text { Espanha e Taiwan }\end{array}$ & 11 & 1.581 \\
\hline $\begin{array}{l}\text { Renda } \\
\text { média }\end{array}$ & $\begin{array}{l}\text { Afeganistão, Argentina, Argélia, } \\
\text { Bolívia, Botsuana, Brasil, } \\
\text { Camarōes, Chile, Chipre, } \\
\text { Colômbia, Congo, Costa do } \\
\text { Marfim, Costa Rica, Coreia } \\
\text { do Sul, El Salvador, Equador, } \\
\text { Filipinas, Gabão, Guatemala, } \\
\text { Irã, Iraque, Iugoslávia, Jamaica, } \\
\text { Jordânia, Malásia, Malta, } \\
\text { Marrocos, Maurício, México, } \\
\text { Panamá, Papua Nova-Guiné, } \\
\text { Paraguai, Peru, Portugal, Senegal, } \\
\text { Síria, Suazilândia, Tailândia, } \\
\text { Trinidad e Tobago, Tunísia, } \\
\text { Turquia, Uruguai e Venezuela }\end{array}$ & 43 & 4.467 & $\begin{array}{l}\text { Argélia, Argentina, Barbados, } \\
\text { Bolívia, Bósnia-Herzegovina, } \\
\text { Botsuana, Brasil, Camarões, } \\
\text { Chile, Colômbia, Congo, } \\
\text { Costa Rica, Croácia, Djibuti, } \\
\text { Dominica, República } \\
\text { Dominicana, Equador, } \\
\text { El Salvador, Fiji, Gabão, } \\
\text { Guatemala, Indonésia, Irã, } \\
\text { Iraque, Jamaica, Jordânia, } \\
\text { Coreia do Sul, Líbano, } \\
\text { Macedônia, Malásia, Maldivas, } \\
\text { Maurício, México, Marrocos, } \\
\text { Omã, Panamá, Papua Nova- } \\
\text { Guiné, Paraguai, Peru, Filipinas, } \\
\text { Portugal, Romênia, Senegal, } \\
\text { Eslovênia, Ilhas Salomão, } \\
\text { Suazilândia, Síria, Tailândia, } \\
\text { Trinidad e Tobago, Tunísia, } \\
\text { Turquia, Uruguai, Venezuela, } \\
\text { Samoa Oeste e Iugoslávia. }\end{array}$ & 55 & 54.747 \\
\hline $\begin{array}{c}\text { Renda } \\
\text { baixa }\end{array}$ & $\begin{array}{l}\text { Benin, Burquina Fasso, Burundi, } \\
\text { Chade, Etiópia, Gana, Guiana, } \\
\text { Guiné, Haiti, Honduras, Índia, } \\
\text { Indonésia, Lesoto, Libéria, } \\
\text { Madagascar, Maláui, Mali, } \\
\text { Mauritânia, Nicarágua, Níger, } \\
\text { Nigéria, Paquistão, Quênia, } \\
\text { República Central Africana, Serra } \\
\text { Leoa, Somália, Sri Lanka, Sudão, } \\
\text { Tanzânia, Togo, Uganda, Zaire, } \\
\text { Zâmbia e Zimbábue }\end{array}$ & 34 & 3.309 & $\begin{array}{l}\text { Afeganistão, Bangladesh, Benin, } \\
\text { Burquina Fasso, Burundi, } \\
\text { República Central Africana, } \\
\text { Chade, China, Comores, Costa } \\
\text { do Marfim, Egito, Guiné } \\
\text { Equatorial, Etiópia, Gâmbia, } \\
\text { Gana, Guiné, Guiné-Bissau, } \\
\text { Guiana, Haiti, Honduras, } \\
\text { Índia, Quênia, Laos, Lesoto, } \\
\text { Libéria, Madagascar, Maláui, } \\
\text { Mali, Mauritânia, Mianmar, } \\
\text { Nepal, Nicarágua, Níger, } \\
\text { Nigéria, Paquistão, Ruanda, } \\
\text { Serra Leoa, Somália, Sri Lanka, } \\
\text { Sudão, Tanzânia, Togo, Uganda, } \\
\text { Vietnã, Iêmen, Zaire, Zâmbia } \\
\text { e Zimbábue }\end{array}$ & 48 & 34.093 \\
\hline
\end{tabular}

Fonte: Kapur et al. (1997: 140 e 234).

(a) O período McNamara inclui os compromissos de $1^{\circ}$ de julho de 1968 a 30 de junho de 1982, com base no pressuposto de que os compromissos de empréstimo feitos durante o ano fiscal de 1982 refletem decisões e preparação realizadas sob McNamara. 
Tabela 2. Empréstimos do Banco Mundial por setor - 1961-82

\begin{tabular}{|c|c|c|c|}
\hline Setores & $1961-69$ & $1969-73(\mathrm{a})$ & $1974-82$ \\
\hline Transporte, energia e telecomunicações (b) & 64.1 & 47 & 35 \\
\hline Agricultura & 12.2 & 20 & 29 \\
\hline Educação & 2.5 & 5 & 4 \\
\hline População, saúde e nutrição & 0 & 1 & 1 \\
\hline Desenvolvimento urbano & 0 & menos de 0.5 & 2 \\
\hline Água e saneamento & 1.7 & 5 & 5 \\
\hline Outros (c) & 19.5 & 21.5 & 24 \\
\hline
\end{tabular}

Fonte: Kapur et al. (1997: 141 e 235).

(a) O período McNamara inclui os compromissos de $1^{\circ}$ de julho de 1968 a 30 de junho de 1982, com base no pressuposto de que os compromissos de empréstimo feitos durante o ano fiscal de 1982 refletem decisóes e preparação realizadas sob McNamara. (b) Inclui mineração. (c) Inclui as seguintes rubricas: créditos para importação industrial; assistência técnica e créditos para importação comercial; finanças; indústria e ajustamento estrutural.

Em nome do "ataque à pobreza", os empréstimos para o quinquênio 1968-73 deveriam ultrapassar a marca do que havia sido desembolsado nos primeiros vinte anos de operações. E para cada Estado cliente foram estabelecidas metas anuais de empréstimos e se definiu que a eficiência profissional de cada funcionário seria avaliada segundo o volume de recursos envolvido nos projetos sob sua responsabilidade. ${ }^{18} \mathrm{O}$ imperativo de "mover o dinheiro" a qualquer custo se tornou, desse modo, um dos traços mais marcantes da cultura organizativa do Banco. Para criar a demanda pelos seus recursos financeiros, o Banco enviava seus técnicos para que vendessem projetos financiáveis aos governos dos Estados clientes. ${ }^{19}$ Por sua vez, do ponto de vista governamental, o acesso ao dinheiro do Banco funcionava como um catalisador de empréstimos externos públicos e privados.

Como parte desse movimento expansivo e da crescente ênfase no setor rural, em 1969 o Banco se articulou às fundações Ford e Rockefeller para criar uma rede internacional de centros de pesquisa agrícola para impulsionar a difusão mundial dos pacotes de modernização tecnológica da chamada revolução verde. A iniciativa culminou em 1971 com a criação do Grupo Consultivo para a Pesquisa Agrícola Internacional (CGIAR). ${ }^{20}$ De imediato, o novo sistema ganhou forte apoio público e privado e nos seus primeiros dez anos o número de doadores (governos, agências multilaterais e fundaçôes) saltou de 16 para 33. Dois lideraram a lista: a Agência dos Estados Unidos para o Desenvolvimento Internacional (USAID), responsável por um quarto do total dos fundos, e o Banco Mundial, responsável por dez por cento dos recursos. ${ }^{21}$

No início dos anos setenta saíram as pesquisas sobre a primeira geração de variedades de trigo e arroz de alto grau de resposta a agrotóxicos e fertilizantes produzidas no México e nas Filipinas e serviram para estimular a difusão do plantio. Os resultados excepcionais de algumas colheitas reforçaram a ideia de que investir no CGIAR era um negócio altamente lucrativo. ${ }^{22}$ Articulado com seus parceiros bilaterais, o Banco estimulou com empréstimos e assistência técnica os Estados clientes a criarem centros de investigação agropecuária. Como mostrou Michael Goldman, ${ }^{23}$ a malha de instituições vinculadas ao CGIAR rapidamente se ampliou e se ramificou pelos âmbitos da ciência, das agências públicas de assistência bilateral e multilateral e das empresas agroindustriais privadas, originando um complexo de poder baseado em um tipo específico de produção de conhecimento, estreitamente atrelado às necessidades de valorização das grandes corporações do setor e às exigências políticas da Guerra Fria de se promover a revolução "verde" como prevenção contra a revolução "vermelha". Milhares de técnicos e cientistas passaram a ser educados pelo sistema CGIAR e muitos deles depois ocuparam posições de destaque como ministros de Estado e membros de diretorias de centros de pesquisa e empresas multinacionais. 


\section{A construção político-intelectual do "ataque à pobreza" durante a gestão McNamara}

A estruturação da área de pesquisa econômica no Banco Mundial ganhou apoio decisivo no início dos anos setenta, com a criação do cargo de economista-chefe, para o qual foi nomeado Hollis Chenery, ex-funcionário da USAID e professor de Economia em Stanford e Harvard. Além disso, o departamento de pesquisa recebeu fartos recursos para se equipar, contratar pesquisadores, pagar viagens e financiar publicações. A sua missão era estabelecer uma base sólida de dados e conceitos para a formulação mais abrangente de políticas e programas econômicos e, assim, apoiar a expansão das operações financeiras. Cabia-lhe também coordenar esforços para encontrar os meios replicáveis necessários à operacionalização de projetos "sociais".

Durante o primeiro quinquênio da gestão McNamara, o Banco oscilou entre diversos instrumentos preferenciais para levar adiante a sua "cruzada contra a pobreza". ${ }^{24}$ Pensou-se em planejamento familiar e controle populacional, nutrição, saúde, educação, urbanização de favelas, entre outros. Enfim, ao lado dos projetos agrícolas, diversos outros projetos em áreas distintas pareceram constituir, em algum momento, o carro-chefe do "combate à pobreza", sem se firmarem como tais.

Note-se que, enquanto questão teórica, a pobreza era um assunto praticamente desconsiderado pela doutrina econômica dominante. $\mathrm{Na}$ literatura acadêmica, o tema figurava de modo vago e pejorativo, frequentemente associado à beneficência e ao assistencialismo. ${ }^{25}$ Antes de McNamara, aliás, a agenda extra-econômica do Banco Mundial falava em "necessidades sociais", não em "pobreza". A própria palavra não fazia parte do vocabulário corrente do staff. $\mathrm{O}$ assunto não foi objeto de declaração alguma nos anos cinquenta e apareceu apenas timidamente durante a maior parte dos anos sessenta. ${ }^{26}$

Com raízes diretas nas injunções da Guerra Fria e enxertada no Banco a partir do governo norteamericano, a "luta contra a pobreza" careceu, naqueles anos, de dois elementos importantes: um enfoque que lhe desse suporte e racionalidade e um instrumento operacional que permitisse a sua replicação em larga escala. O Banco não tinha uma abordagem que conferisse coerência, para fora e para dentro, aos projetos que a instituição já vinha executando em agricultura, educação e desenvolvimento urbano. Também não tinha um instrumento preferencial que nucleasse a sua "cruzada contra a pobreza" e permitisse a aferição estatística dos seus resultados. Ou seja, não havia uma teoria nem um meio passível de replicação e avaliação "econômica" de resultados.

Ambos surgiram somente no biênio 1973-74, com a definição da "pobreza rural absoluta” como alvo principal da intervenção do Banco por meio dos novos projetos de "desenvolvimento rural integrado" (DRI), e com a publicação do livro coordenado por Hollis Chenery, Redistribuição com crescimento. Daí nasceu o enfoque orientado à pobreza (poverty-oriented approach), a partir do qual o Banco se firmou como paladino da "luta contra a pobreza". Para entender esse processo é preciso considerar três ordens de fatores.

Em primeiro lugar, a macropolítica da Guerra Fria. Somados à derrocada dos EUA no Vietnã, outros acontecimentos ocorridos durante o quinquênio 1968-73 empurraram Washington e seus aliados mais próximos à busca de novas estratégias de atuação, pressionando as organizaçōes que integram a sua rede de poder externo, como o Banco Mundial, a fazerem o mesmo. A lista é longa: eleição, governo e derrubada de Allende no Chile, eleição de Indira Gandhi, guerra entre Índia e Paquistão e fundação de Bangladesh, nacionalização do petróleo e reforma agrária no Peru, entre outros. ${ }^{27}$ Em todos os casos, embaladas pelo nacionalismo, políticas de cunho distributivo e redistributivo, gozavam de forte popularidade, e o fiel da balança era, na leitura do establishment norte-americano, o campesinato. Como afirmou Samuel Huntington, em seu clássico publicado originalmente em 1968: "Quem controla o interior controla o país. (...) Se os camponeses aceitam e se identificam com o sistema existente, isso proporciona uma base estável ao sistema. Se os camponeses se opõem ativamente ao sistema, passam a ser os portadores da revolução". ${ }^{28}$ Ganhar o apoio desse segmento ou, pelo menos, desativar o seu ativismo, era considerado estratégico. ${ }^{29}$ 
Em segundo lugar, a construção do enfoque orientado à pobreza seria impensável sem o questionamento ao "efeito derrame" por dentro do próprio paradigma dominante..$^{30}$ A expressão "a derrocada do PIB”, pronunciada em 1970 por David Morse, diretor geral da Organização Internacional do Trabalho (OIT), para definir a perda de confiança no crescimento econômico como meio suficiente para reduzir a pobreza, rapidamente fez fortuna, escancarando aquele questionamento. ${ }^{31}$

Em terceiro lugar, a construção do enfoque orientado à pobreza do Banco Mundial esteve diretamente ligada a mudanças na política norte-americana de ajuda externa ao desenvolvimento. As críticas acadêmicas e de dentro da rede da assistência internacional engrossavam a pressão geral sobre o governo dos EUA, cujo envolvimento na guerra do Vietnã a cada dia gerava níveis mais altos de desgaste político. Assim, em 1973, o Congresso aprovou uma nova legislação (Foreign Assistance Act, PL 93-189), mais conhecida como Novas Direções, que reorientou a ajuda externa bilateral. Pautando-se pela ideia de atendimento direto às "necessidades humanas básicas", a nova diretriz tinha como foco a redução da "pobreza extrema" mediante a concessão de crédito para o aumento da produtividade de "pequenos agricultores" ${ }^{32}$ A rigor, não se tratava de uma novidade, mas sim da retomada, sob nova roupagem, de iniciativas postas em prática pelo governo estadunidense desde os anos 1950 e 1960 com o Desenvolvimento de Comunidade e a Aliança para o Progresso. De todo modo, as Novas Direções repercutiram diretamente na busca, pela gestão McNamara, de uma maior coerência entre a sua retórica pro-poor e a qualidade da carteira de projetos do Banco Mundial voltados a esse fim.

Internamente, um passo decisivo para a construção do enfoque orientado à pobreza foi a definição da "pobreza absoluta" como unidade de análise e critério operacional. ${ }^{33}$ Esse movimento se consolidou no biênio 1972-73, culminando em 1974 com a publicação do livro coordenado por Chenery. O discurso de McNamara em 1972 foi um marco dessa guinada:

Quando os privilegiados são poucos e os desesperadamente pobres são muitos, e quando a brecha entre ambos os grupos se aprofunda em vez de diminuir, é apenas uma questão de tempo até que seja preciso escolher entre os custos políticos de uma reforma e os riscos políticos de uma rebelião. Por este motivo, a aplicação de políticas especificamente encaminhadas para reduzir a miséria dos quarenta por cento mais pobres da população dos países em desenvolvimento é aconselhável não somente como questão de principio, mas também de prudência. ${ }^{34}$

No ano seguinte, em um discurso histórico em Nairóbi, McNamara ${ }^{35}$ reiterou a menção aos quarenta por cento mais pobres; dessa vez, porém, sua mensagem apareceu codificada numa estratificação da pobreza em duas categorias: relativa e absoluta. A novidade dava suporte operacional à identificação de "focos de pobreza" absoluta no meio rural, que deveriam, então, ser "atacados" mediante projetos de "desenvolvimento rural" voltados para o aumento da produtividade da terra de "pequenos agricultores" que financiassem a aquisição e a aplicação de pacotes tecnológicos de ponta (agrotóxicos, sementes melhoradas geneticamente, máquinas e equipamentos etc.). Ou seja, tratava-se de implementar uma "pequena revolução verde" em parcelas do campesinato. ${ }^{36}$ Adicionalmente, McNamara propôs a realização de programas de obras rurais de pequeno e médio porte para gerar emprego temporário não-agrícola no campo a baixo custo para o contingente cada vez maior de trabalhadores rurais sem-terra.

Os projetos de desenvolvimento rural tinham como pressuposto a aceitação da estrutura agrária. A concentração da propriedade da terra - fator elementar de determinação da pobreza e desigualdade social - foi tomada como um dado ao qual os projetos deviam se acomodar. ${ }^{37}$ Por isso, o itinerário proposto por McNamara constituía uma alternativa conservadora e reacionária à reforma agrária, apesar do discurso evasivo a seu favor.

Publicado no ano seguinte, Redistribuição com crescimento academizou o discurso de McNamara em Nairóbi e deu ao Banco um núcleo teórico que lhe permitiu vender com mais eficácia seu novo produto - o desenvolvimento rural integrado - no mercado internacional de ideias, ${ }^{38}$ ao instituir a pobreza absoluta e os grupos-alvos como categorias operacionais legítimas para as políticas públicas. 
O livro partia da distinção entre pobreza absoluta e relativa, deixando de lado a questão da desigualdade na distribuição de renda e da pobreza relativa e trazendo para o primeiro plano o aumento da renda e a redução da pobreza absoluta. A tese fundamental era a de que a redução da pobreza absoluta não era incompatível com o crescimento da economia. Como, então, aumentar a renda dos "pobres"? Chenery e seus colaboradores listaram quatro estratégias distintas: a) a maximização do crescimento do PIB através do aumento das poupanças e de uma melhor alocação dos recursos, o que beneficiaria, acreditavam os autores, todos os grupos da sociedade; b) a reorientação do investimento para os gruposalvo em "pobreza absoluta" sob a forma de educação, acesso ao crédito, obras públicas etc.; c) a redistribuição de renda ou consumo para os grupos-alvo através do sistema fiscal ou da transferência direta de bens de consumo; d) a redistribuição de ativos existentes para os segmentos mais pobres, por meio de políticas como a reforma agrária. ${ }^{39}$ A proposta central do livro consistia em "concentrar o investimento público no aumento da capacidade produtiva e dos rendimentos dos pobres", ${ }^{40}$ ou seja, a segunda estratégia. As demais foram descartadas no todo ou em parte: a primeira por reforçar ainda mais a concentração de renda; a terceira por consumir em excesso recursos de maneira "não-produtiva"; a quarta pelo seu "alto custo de desorganização social e política" e a sua não aplicabilidade em larga escala. ${ }^{41}$

A rigor, tratava-se de uma estratégia distributiva de tipo incremental, na medida em que se limitava a distribuir parte do crescimento econômico (rendas e ativos novos) mediante projetos e programas financiados através de captação de impostos e endividamento externo. Em tese, tais ações fomentariam o aumento da "produtividade dos mais pobres", de tal forma que, por meio da sua inserção mercantil, a renda dos mesmos se elevasse. Repartir um pedaço do crescimento do bolo, e não o bolo: era isso o que propunha o Banco Mundial. ${ }^{42}$

O título do livro evocava o que, precisamente, era negado pelo seu conteúdo: a ideia de redistribuição, tanto no plano governamental como no plano social. No primeiro caso, por condicionar o "investimento público nos mais pobres" à elevação da receita pública proporcionada pelo aumento da produtividade média da economia e dos índices de crescimento; ou seja, à acumulação de capital. Ora, um esquema dessa natureza permitia aumentar, em termos absolutos, o gasto em "combate à pobreza", mas não alterava a sua cota relativa no orçamento público. No segundo caso, a proposta deixava incólume o estoque de riqueza existente (rendas e ativos acumulados) e todo o arcabouço jurídico-institucional - as regras do jogo, por assim dizer - que garante a sua preservação. Em outras palavras, permaneciam intocados o regime de propriedade e a estrutura de produção.

Apesar da crítica ao "efeito derrame", McNamara e sua equipe jamais pretenderam superar o paradigma dominante, mas sim encontrar uma maneira de revisá-lo lateralmente, a fim de acomodá-lo ao modelo econômico convencional e à ideologia liberal do Banco Mundial. ${ }^{43}$ Por outro lado, como Redistribuição com crescimento descartava qualquer concessão por parte dos setores dominantes, a sua estratégia incremental de distribuição carecia de uma teoria política. Assim, a coalizão capaz de impulsionar o enfoque proposto surgia, no texto, como um dado. Isso explica as exortações vazias de McNamara por "vontade política", "coragem" e "obrigação moral" dos mais ricos de "ajudar os pobres e os fracos". ${ }^{44}$

De todo modo, o livro serviu para dar suporte a uma espécie de "pobretologia", ${ }^{45}$ isto é, à imposição da pobreza como unidade de análise, parâmetro legítimo e foco obrigatório para toda e qualquer iniciativa no âmbito da assistência ao desenvolvimento. A institucionalização da redução da pobreza como parte da agenda internacional esteve diretamente ligada ao envolvimento cada vez maior do Banco Mundial, a partir dos anos setenta, em pesquisa (em particular, análises de inputs-outputs e de custo-benefício), produção, compilação e disseminação de dados. Surgiu um corpo interno de conhecimento, ligando um documento a outro para sua evidência e argumentação, reforçando e amalgamando ideias e práticas. O Banco também passou a financiar a pesquisa local e a formar técnicos para fins de produção de dados e desenho de projetos ligados ao tema ${ }^{46}$ A partir dessas iniciativas, constituiu-se todo um campo de pesquisa dedicado a essa temática. Enfim, não apenas se estabeleceu um modo de interpretar e categorizar a realidade social, como também a questão social, com base na "ciência da pobreza" e na "ciência da gestão política da pobreza” pela via do crédito (e não da filantropia stricto sensu). 
O conceito de que a superação da pobreza rural e urbana dar-se-ia pelo aumento da "produtividade dos pobres" tinha como premissa a ideia de que vivia em tais condições apenas quem não estivesse inserido em atividades consideradas produtivas e rentáveis. Tal proposição operava um triplo movimento: primeiro, apagava o caráter desigual e combinado das formas de exploração e, portanto, a "funcionalidade dos pobres" (desempregados, subempregados, pequenos agricultores etc.) para a acumulação capitalista; segundo, isolava a pobreza do conjunto das relaçôes sociais, como se fosse um fenômeno em si mesmo; terceiro, reificava as modalidades mais predatórias de desenvolvimento capitalista, na medida em que explicava a pobreza como exclusão do progresso, e não como um dos seus resultados. ${ }^{47}$ Esse triplo movimento permitiu ao Banco fortalecer politicamente o preceito da luta contra a pobreza, ao fazê-lo parecer auto-explicativo e legítimo por si próprio. Permitiu, também, eludir a questão dos baixos salários e da necessidade de criação de empregos, na medida em que deslocava o foco de análise para a qualidade da inserção atomizada dos indivíduos no mercado.

Ao mesmo tempo em que deslanchava os projetos de desenvolvimento rural, o Banco Mundial se engajou, de 1973 até 1981, na procura por um instrumento análogo para o meio urbano, isto é, um tipo de projeto que pudesse ser replicado de forma rápida e em maior escala, que tivesse uma populaçãoalvo mais ou menos bem definida e que servisse de veículo para investimentos considerados produtivos, e não apenas para transferências sociais. ${ }^{48} \mathrm{O}$ tema foi objeto do discurso de McNamara em 1975, mais uma vez numa perspectiva política explícita:

Historicamente, a violência e os distúrbios civis são mais comuns nas cidades que no âmbito rural. Entre os grupos urbanos de baixa renda as frustrações se inflamam e são facilmente aproveitadas pelos extremistas políticos. Se as cidades não começarem a tratar de maneira mais construtiva o problema da pobreza, esta pode muito bem começar a tratar de maneira mais destrutiva as cidades. Este não é um problema que admita demora por razões políticas. ${ }^{49}$

Diversos documentos setoriais foram publicados entre 1974 e 1976 e se criou um grupo de trabalho para assegurar a implementação do novo objetivo: minorar a pobreza urbana - "absoluta", sempre. Focalização e produtividade eram as palavras-chave. Os primeiros projetos do Banco, autorizados ainda em 1972, seguiam o enfoque de "terrenos e serviços" (sites and services), cujo objetivo era de prover uma abordagem replicável que conciliasse recuperação de custos (cobrança de taxas) máxima e subsídio público mínimo. Em outras palavras, seu objetivo central era demonstrar a viabilidade financeira e política de um modelo da habitação urbana de baixo padrão que pudesse substituir os esquemas tradicionais de fornecimento público de moradia. O procedimento básico consistia em limitar ao mínimo possível a provisão pública para a compra da terra e a construção de infraestrutura básica, deixando aos novos proprietários a responsabilidade e grande parte dos custos da autoconstrução das casas. Posto em prática pelo Banco Interamericano de Desenvolvimento e pela USAID desde o início dos anos sessenta, tal enfoque fornecia um meio para se explorar o trabalho não-pago, rebaixar o custo de reprodução da força de trabalho e alimentar o conformismo social por meio do acesso à propriedade como blindagem contra o "assédio comunista". Além de problemas de ordem legal relacionados à compra dos terrenos, o enfoque sites and services mostrou-se não-replicável, porque o padrão dos terrenos e da provisão de serviços era rebaixado a níveis tão aviltantes, para que os "consumidores" pudessem pagar, que requeria subsídios adicionais. ${ }^{50}$

$\mathrm{Na}$ tentativa de ampliar o grau de cobertura, acelerar a implementação e baixar custos, o Banco Mundial passou a priorizar, então, a "urbanização de favelas" (slum upgrading). O novo enfoque exigia o mínimo de demolição física e reassentamento de pessoas, com a vantagem de servir ideologicamente à canonização da habitação favelada, ao discurso do "ajudar os pobres a ajudarem a si próprios" e à ilusão incremental do "construa-você-mesmo". ${ }^{51}$ No entanto, essa abordagem logo mostrou não ter resolvido o problema da focalização nos segmentos mais pobres, em parte porque o próprio Banco não abria mão da recuperação de custos. 
Como a estratégia de moradia urbana de baixos padrões corria na direção contrária à dos códigos legais de habitação existentes na grande maioria dos países prestatários, o Banco Mundial fomentou a criação de diversas agências autônomas ou autoridades nacionais responsáveis pela política habitacional. ${ }^{52}$ Com frequência, tais organismos ajudaram a blindar as decisões-chave da política urbana contra a prestação de contas e o voto popular. No conjunto, as prescrições do Banco nessa matéria se direcionaram para a minimização do papel do Estado na resolução do déficit habitacional. ${ }^{53}$

Entre 1976 e 1979, o Banco Mundial também se envolveu com o debate sobre "necessidades básicas". A discussão foi lançada pela OIT como uma suposta redefinição do enfoque orientado à pobreza, dando peso à "necessidade" como critério de decisão para a delimitação de projetos e a alocação de recursos. De novo, o Banco Mundial reagia à OIT. ${ }^{54}$ Todavia, não só a ela: a ideia de necessidades sociais, mais do que a de pobreza, figurava no vocabulário do Banco desde a gestão Woods; ademais, a ideia de necessidades básicas orientava formalmente a política de assistência bilateral norte-americana, revisada em 1973.

O novo enfoque rivalizava com aquele academizado por Chenery, sem, no entanto, suplantá-lo. Internamente, a gestão McNamara debateu durante os cinco ou seis anos seguintes quais seriam as necessidades básicas desejáveis ou possíveis, como justificá-las em termos de custo/benefício e de que modo assumir que o crescimento não seria prejudicado. ${ }^{55}$ Afinal, um dos pilares do discurso de $\mathrm{McNa}$ mara era a negação de trade-offs entre crescimento econômico e redução da pobreza (ou, no caso, satisfação de necessidades básicas). $\mathrm{O}$ debate não chegou a lugar algum e pouco se traduziu em projetos ou componentes de projetos. ${ }^{56}$

O objetivo do novo enfoque não era negar a teoria do derrame. ${ }^{57}$ Como explicou McNamara: "se as pessoas que vivem na pobreza absoluta tivessem que esperar que os benefícios do crescimento econômico global fossem filtrados até elas, o ritmo em que melhorariam seus rendimentos e nível de bemestar seria intoleravelmente pequeno" ${ }^{58} \mathrm{Ou}$ seja, tratava-se tão-somente de complementar, por meio de ações variadas, o gotejamento que, em tese, ocorria, então, numa velocidade politicamente inaceitável. Ademais, tal como acontecia com a redução da pobreza, a satisfação das necessidades básicas também era tomada como um objeto isolado do conjunto das relaçôes sociais e da política econômica, desconsiderando-se o desemprego e o rebaixamento da remuneração da força de trabalho. ${ }^{59}$

Todavia, a movimentação em torno das necessidades básicas acabou por consagrar saúde e educação primárias como áreas abertas ao investimento produtivo nos países da periferia. O Banco seguiu essa linha, destacando-se por subordiná-las aos imperativos políticos do aliviamento da pobreza absoluta e da reformulação e redução do gasto público com políticas sociais. No final de 1979, McNamara criou o Departamento de População, Saúde e Nutrição, o que permitiu a autorização de empréstimos exclusivamente para a saúde - antes, o setor figurava apenas como um componente em projetos de desenvolvimento rural e urbano e planejamento familiar — , abrindo um campo novo e amplíssimo de atuação que cresceria enormemente nos anos seguintes. Enquanto isso, a entrega do Prêmio Nobel de Economia para Theodor Schultz, no mesmo ano, serviu para entronizar tardiamente o conceito de capital humano na agenda educacional do Banco. Os governos dos EUA e do Reino Unido apoiaram entusiasticamente, no Conselho de Governadores do Banco, a ênfase na educação básica. Em 1980, a publicação anual mais importante do Banco, o Relatório sobre Desenvolvimento Mundial (RDM), chancelou as duas novas prioridades na área social. Gestavam-se, naquele momento, as coordenadas principais de um modelo de política social que se tornaria hegemônico uma década depois, centrado na formação de capital humano.

Apesar de todas as exortaçôes em prol da "luta contra a pobreza extrema", ao longo da gestão McNamara os empréstimos do Banco para projetos com algum componente (não necessariamente majoritário) "orientado à pobreza" oficialmente não ultrapassaram um terço do total. Entretanto, esta cifra está superestimada, pois o staff exagerava o grau de cobertura dos projetos, aumentando o número de beneficiários considerados pobres, pois a ascensão profissional dependia do volume de empréstimos sob supervisão de cada funcionário. ${ }^{60}$ 
Contudo, quando comparados à magnitude do investimento público realizado pelos Estados clientes, os empréstimos do Banco sempre representaram uma quantia irrisória. Aliás, McNamara logo descobriu isso. Afinal, como Secretário de Defesa dos EUA, ele contara com um orçamento anual de mais de US\$ 70 bilhões, mas quando chegou à presidência do Banco, viu-se diante de uma carteira que totalizava pouco mais de US\$ 1 bilhão ao ano. ${ }^{61}$ Para ele, estava claro que a atuação do Banco só poderia provocar algum impacto no âmbito da formação de ideias e da assistência técnica. Assim, o financiamento funcionava mais como um veículo ou alavanca para a reorientação do gasto público e a remodelagem das políticas estatais. ${ }^{62}$

Ora, se os empréstimos para projetos orientados à pobreza mal representaram um terço do total financiado, pode-se afirmar que o impacto direto de tais projetos foi insignificante. Por outro lado, tanto no meio rural como no meio urbano os projetos do Banco induziram mudanças na composição e na destinação do gasto público, na medida em que, para cada empréstimo contratado com o Banco, os governos tinham de desembolsar uma contrapartida financeira, em geral muito maior; depois, precisavam para pagar o Banco, tido sempre como credor preferencial, e em moeda forte. Além disso, os projetos financiados pelo Banco Mundial forneceram parâmetros e condições para a redefinição de políticas setoriais e sociais em dezenas de países. Em muitos casos, agências e órgãos da administração pública responsáveis pela regulação de setores inteiros da economia foram erguidos a partir de empréstimos e/ou assessoria técnica do Banco. Nas áreas do desenvolvimento rural e urbano, por exemplo, não raro a replicabilidade dos projetos era garantida pela internalização de modelos e procedimentos produzidos e difundidos pelo Banco, o que, na prática, acabava por dispensar a contratação de empréstimos.

Com frequência, esse processo teve conotações políticas reativas e assumiu uma direção conservadora, na medida em que serviu para que governos - na época, majoritariamente sob regimes ditatoriais - eludissem a pressão popular por reformas sociais democratizantes, como a reforma agrária. Por outro lado, é imensa a lista de projetos financiados ou apoiados pelo Banco que provocaram impactos altamente negativos do ponto de vista sócio-ambiental. ${ }^{63}$

Os picos das mensagens políticas do Banco sobre "pobreza" e "necessidades básicas" ocorreram nos anos 1972-74 e 1977-78, quando as exortaçôes messiânicas costumeiras de McNamara sobre a necessidade de se aumentar a ajuda externa subiram de tom e os desembolsos para projetos sociais ganharam um empurrão adicional. Também em ambos os períodos o Banco empreendeu iniciativas com o objetivo de introduzir o tema da "redução da pobreza" na relação com alguns governos de países clientes com histórico de concentração de renda muito elevada. Contudo, como já foi demonstrado, ${ }^{64}$ tais iniciativas foram bastante pontuais e, sem exceção, preteridas em nome de emergências políticas e/ou financeiras, as quais demandavam, na visão do Banco, a manutenção do foco do diálogo político em problemas macroeconômicos e a continuidade da escalada de empréstimos.

Do ponto de vista político, a distensão (détente) da Guerra Fria jogou um papel importante na queda dos empréstimos para fins "sociais". ${ }^{65}$ Iniciada pelo primeiro governo Nixon (1969-72), a détente relaxou as tensōes entre as superpotências, abriu os países do bloco socialista ao capital privado europeu e norte-americano e normalizou progressivamente as relações diplomáticas dos EUA com a China. ${ }^{66}$

Contudo, as contradiçôes decorrentes dos significados distintos que EUA e URSS atribuíam à détente acabaram engolindo-a, à medida que diversos eventos se sucediam no cenário político internacional, entre 1973-74 e 1977-78: a eclosão de golpes militares e massacres no Chile, na Argentina e em Uganda, o escândalo do Watergate e a renúncia de Nixon, a guerra de secessão do Paquistão, a guerra do Yom Kipur no Oriente Médio, a ditadura do Khmer Vermelho no Camboja, a Revolução dos Cravos em Portugal, a derrocada da ditadura na Grécia, a crise da ditadura franquista na Espanha e as guerras civis no Líbano, em Angola, no Zaire, na Etiópia e em muitos outros países africanos (em alguns casos, com a presença militar ativa da URSS). ${ }^{67}$

À instabilidade no plano político internacional se somava a instabilidade econômica. De um lado, desde o final dos anos sessenta, as tensões no sistema monetário internacional tornavam a manutenção 
da convertibilidade do dólar em ouro cada vez mais difícil para os EUA. Assim, os EUA romperam unilateralmente com o regime monetário de Bretton Woods, mediante uma sequência de medidas praticadas pelo governo Nixon: em 1971, o corte da ligação entre o dólar e o ouro; em 1973, o abandono do sistema de paridades fixas, mas ajustáveis, em favor de taxas de câmbio flutuantes; em 1974, o fim das restrições ao fluxo de capitais nos EUA. ${ }^{68}$ Essa movimentação fez parte da estratégia de destruição das regras que limitavam o domínio dos EUA sobre a política monetária internacional, por meio da transformação do regime monetário baseado no padrão ouro-dólar num regime baseado exclusivamente no padrão dólar. ${ }^{69}$ De outro lado, os países centrais sofriam a combinação de inflação, baixo crescimento e aumento do desemprego - em particular, após o primeiro choque do preço do petróleo, no final de 1973 - e respondiam, cada vez mais, com políticas defensivas do ponto de vista comercial e monetário. ${ }^{70}$ Por sua vez, alguns poucos países da periferia (como Brasil, México, Coreia do Sul e Taiwan) seguiam com altas taxas de crescimento econômico ao longo de toda a década, à custa de um endividamento externo contraído em ritmo galopante, oriundo do acesso ao crédito farto e barato oferecido por bancos privados internacionais encarregados de reciclar a renda petrolífera. Enquanto isso, a grande maioria dos países da periferia não-exportadores de petróleo empobrecia ou apresentava taxas de crescimento baixas. ${ }^{71}$

Por tudo isso, dentro do seu campo de ação, onde a estabilidade política e econômica estava sob ameaça, o Banco Mundial se concentrou no apoio a governos afinados e na concessão de mais e mais empréstimos que viabilizassem sucessivas fugas para frente. ${ }^{72}$

\section{O ajustamento estrutural e a remodelagem da política social (1980-1990)}

Depois de 1979, os projetos "sociais", que até então haviam representado uma fração minoritária da carteira do Banco, passaram a representar menos ainda, e a bandeira do "ataque à pobreza" gradualmente deixou de figurar no centro do discurso público de McNamara. É que depois do segundo choque do preço do petróleo e do aumento brusco da taxa de juro norte-americana, ambos em 1979, o Banco Mundial passou a concentrar ainda mais a sua carteira de empréstimos em modalidades que permitissem desembolsos elevados, apoiassem diretamente o balanço de pagamentos e servissem à obtenção de divisas que possibilitassem a rolagem dos débitos e a manutenção da espiral de endividamento. ${ }^{73}$ Nessa direção, as somas emprestadas pelo Banco dobraram entre os anos fiscais de 1978 e 1981, concentrando-se em alguns clientes preferenciais (como México, Brasil, Argentina, Índia, Paquistão, Indonésia e Turquia), todos altamente endividados. ${ }^{74}$

Em maio de 1979, McNamara anunciou a criação de um novo instrumento financeiro: o empréstimo de ajustamento estrutural ${ }^{75}$. De desembolso rápido e orientado para políticas, e não para projetos, tinha o objetivo de financiar o déficit no balanço de pagamentos, sobretudo de países importadores de petróleo. A autorização desse tipo de empréstimo estava condicionada à realização, pelo prestatário, de um programa de estabilização acordado previamente com o FMI e de um pacote de reformas na política macroeconômica, ambos voltados para adequar a economia doméstica ao novo ambiente externo e manter o pagamento do serviço da dívida externa. No biênio 1980-81, o Banco atuou no sentido de firmar o "ajustamento estrutural" como meio necessário para adaptar e enquadrar os países endividados às novas condições da economia internacional, seguindo de perto a nova divisão de trabalho entre "Estado" e "mercado" que emergia como expressão institucional de um duplo movimento: de um lado, a pressão neoliberal encabeçada pelos governos Thatcher e Reagan; de outro, a mudança mais geral na correlação de forças entre capital e trabalho. Não por acaso, desde 1978 o Banco já esboçava os contornos gerais da crítica neoclássica ao estilo de desenvolvimento baseado na substituição de importações e todas as políticas prescritas para reduzir o déficit público atacavam, primeiro e preferencialmente, direitos sociais e trabalhistas que, até então, configuravam certo balanço de poder entre capital e trabalho.

O primeiro empréstimo de ajustamento estrutural foi aprovado pelo Banco em março de 1980 para a Turquia e representou, na visão do Banco, um "protótipo" para os seguintes. ${ }^{76}$ No âmbito das políti- 
cas macroeconômicas, as medidas de ajustamento preconizadas pelo Banco consistiam em: liberalizar o comércio, alinhar os preços ao mercado internacional e baixar tarifas de proteção; desvalorizar a moeda; fomentar a atração de investimento externo e a livre circulação de capitais; promover a especialização produtiva e expandir as exportaçóes, sobretudo agrícolas. No âmbito das políticas sociais e da administração estatal, o ajuste tinha como meta central a redução do déficit público, especialmente por meio de medidas como: a) o corte de gastos com pessoal e custeio da máquina administrativa; b) a redução drástica ou mesmo a eliminação de subsídios ao consumo; c) a redução do custo per capita dos programas, a fim de ampliar o grau de cobertura; d) a reorientação da política social para saúde e educação primárias, mediante a focalização do gasto na parcela da população em condições de "pobreza absoluta". Todo esse conjunto de medidas figurou, de um modo ou de outro, nos relatórios mais importantes do Banco Mundial entre 1978 a 1982 como recomendações de políticas econômicas e setoriais consideradas "responsáveis".

Em agosto de 1982, o governo mexicano declarou moratória e a crise da dívida externa dos países latino-americanos estourou. Era a culminação de um processo de endividamento praticado exaustivamente durante duas décadas. ${ }^{77}$ Entre os anos de 1973 e 1981, o México tinha se endividado pesadamente: os empréstimos do Banco Mundial haviam quadruplicado e os da banca privada se multiplicado por seis. Em 1982, o país tinha cerca de 550 bancos como credores e os estadunidenses eram, de longe, os mais comprometidos. ${ }^{78} \mathrm{~A}$ banca norte-americana, em particular, havia emprestado muito mais do que seus ativos líquidos a autorizavam, sem qualquer tipo de supervisão do Tesouro e com a conivência integral do Banco Mundial e do FMI.

Quando a crise estourou, as autoridades monetárias dos EUA e da Inglaterra, o FMI e o Banco de Pagamentos Internacionais (BIS) se reuniram para traçar a estratégia de gestão da dívida. ${ }^{79}$ Diagnosticaram a crise como um problema de liquidez, e não de solvência, e apontaram que a saída passava pelo pagamento do serviço da dívida. Como gerar os recursos para isso? Mediante a reorientação da produção para bens exportáveis, por meio da redução e do redirecionamento do gasto público. ${ }^{80}$ Ao FMI caberia outorgar pacotes de socorro em troca da execução de programas de estabilização de curto prazo e da estatização das dívidas privadas. Esperava-se que em três, ou cinco anos, as medidas reativassem o crescimento e sustentassem o pagamento do serviço da dívida. $\mathrm{O}$ Banco Mundial logo se juntou àquela estratégia como força auxiliar do FMI. Os programas de ajustamento estrutural, já em curso, foram então instrumentalizados para servir ao enquadramento da política econômica dos devedores às exigências dos credores internacionais. Mecanismos de proteção ou compensação parcial a grupos sociais mais vulneráveis ao ajuste não foram cogitados.

À medida que os efeitos recessivos dos planos de estabilização monetária auspiciados pelo Banco foram aparecendo no Brasil, na Argentina e em outros países, tornou-se claro para os credores públicos e privados que não se tratava de uma mera crise de liquidez. Emergiu, assim, a preocupação com a sustentabilidade política do ajuste. Até então, o discurso oficial tinha sido de que o ajuste simplesmente era "bom para os pobres", pois os beneficiaria diretamente - e não apenas indiretamente, pela via do "derrame" ${ }^{81}$ Esse discurso mudou em meados dos oitenta, quando o Banco começou a admitir a ocorrência de certos "custos sociais". A partir de então, a política de ajuste passou a requerer a criação de programas paliativos de compensação social para aliviar, de maneira seletiva e no curto prazo, o impacto regressivo sobre as parcelas da população mais golpeadas ou mais suscetíveis a apoiarem a oposição. Com frequência, tais operações passaram a ser organizadas por meio de fundos sociais de emergência voltados à conformação de redes de segurança (safety nets).

A primeira operação desse tipo ocorreu na Bolívia, em dezembro de 1986. Segundo o cálculo político do Banco Mundial, ${ }^{82}$ era preciso dar uma resposta governamental "altamente visível" que desarticulasse o protesto social, a fim de garantir a sustentação de uma coalizão de governo comprometida com a implementação de um programa enérgico de ajustamento estrutural.

Desde então, o Banco promoveu a criação de fundos sociais em dezenas de países na África, na Ásia, no Leste Europeu e, sobretudo, na América Latina, por meio de empréstimos e assistência téc- 
nica. Os fundos surgiram como mecanismos multissetoriais capazes de financiar programas e projetos num arco amplo de atividades, desde a criação de empregos temporários e o fornecimento subsidiado de alimentos até a organização local de populações pauperizadas - o que o Banco chama de "fortalecimento das comunidades". Criados para operar como instrumentos de ação transitória e de curto prazo, em poucos anos se tornaram veículos permanentes para a conformação de um novo modelo de política social. ${ }^{83}$ Seu princípio básico é a substituição da oferta universal de bens e serviços públicos pelo atendimento a demandas (demand-driven approach). Por isso, orientam-se pela focalização dos recursos em grupos-alvo, selecionados de acordo com a sua vulnerabilidade aos impactos do ajustamento estrutural. A identificação e execução de projetos e programas ficam a cargo de ONGs, grupos de base, prefeituras e até empresas privadas, ou de consórcios envolvendo todos esses atores. Em geral, as agências criadas para gerir tais fundos operam com ampla autonomia em relação à área social do governo, mesmo que estejam ligadas ou formalmente subordinadas a ministérios específicos. Utilizados como vitrines, costumam alcançar alta visibilidade pública e normalmente contam com um forte apoio político, vinculando-se diretamente a altas instâncias do Estado ou a áreas centrais do governo. Além dos recursos do orçamento nacional, em geral podem contar com fontes extraordinárias de financiamento ligadas a agências bilaterais de ajuda externa e bancos multilaterais.

Enquanto o Banco estimulava a precarização da política social por meio da criação de fundos sociais, seus empréstimos para educação e saúde primárias aumentaram extraordinariamente após 198789, como mostra a Tabela 3. Essa ênfase contribuiu para legitimar essas áreas como prioritárias, em detrimento dos demais segmentos da educação e da saúde.

Tabela 3. Empréstimos do Banco Mundial para setores com foco no aliviamento da pobreza - anos fiscais 1981-93. Médias anuais.

\begin{tabular}{|c|c|c|c|}
\hline Setores & $1981-83$ & $1987-89$ & $1991-93$ \\
\hline Desenvolvimento de recursos humanos & 659 & 1.059 & 3.494 \\
\hline Educação & 603 & 756 & 2.047 \\
\hline População, saúde e nutrição & 56 & 303 & 1.447 \\
\hline Agricultura e desenvolvimento rural & 3.513 & 3.638 & 3.623 \\
\hline Abastecimento de água e saneamento básico & 596 & 765 & 1.097 \\
\hline Total de empréstimos (milhões de dólares) & 13.261 & 19.421 & 22.696 \\
\hline Como parte do total de empréstimos (percentual) & 35 & 28 & 36 \\
\hline Desenvolvimento de recursos humanos & 5 & 5 & 15 \\
\hline Agricultura e desenvolvimento rural & 26 & 19 & 16 \\
\hline Abastecimento de água e saneamento básico & 4 & 4 & 5 \\
\hline
\end{tabular}

Fonte: BANCO MUNDIAL Annual report. Washington DC: The World Bank, 1993. p. 39.

Pouco depois da experiência-piloto na Bolívia, surgiram críticas de dentro do sistema da Organização das Nações Unidas (ONU) em relação à austeridade monetária e fiscal exigida pelos programas de ajustamento do Banco Mundial e do FMI. Um relatório do UNICEF intitulado "ajuste com rosto humano" alcançou rapidamente grande repercussão. ${ }^{84}$ Não se tratava, propriamente, de uma crítica ao mérito do ajuste, mas à sua forma de implementação e a alguns termos do seu conteúdo, como por 
exemplo, o fato de que a política social tivesse sido relegada a posteriori e reduzida a um conjunto de medidas paliativas. Economistas do Banco Mundial refutaram o relatório, alegando a necessidade de se distinguir entre os custos sociais decorrentes das medidas "corretivas" e os custos gerados pelo desequilíbrio macroeconômico per si. Porém, a partir daquele momento, os altos expoentes do Banco deixaram de dizer em público que o ajuste simplesmente era "bom para os pobres". 85

No final de 1989, já sob o governo Bush, algumas das principais forças que impulsionavam a reestruturação capitalista neoliberal realizaram na capital norte-americana uma reunião de avaliação. Estavam lá representantes do Departamento do Tesouro, do Banco Mundial, do FMI, do BID, da USAID e dos principais think tanks estadunidenses. Registrou-se entre eles o acordo amplo sobre o pacote de reformas de política econômica em curso em praticamente todos os países da América Latina e do Caribe, bem como a necessidade de acelerar a sua execução dentro e fora da região. O receituário, publicado em 1990, tomou a forma de um decálogo de prescrições e ficou conhecido como "consenso de Washington". 86

Elaborado sobre os escombros do muro de Berlim e embalado pelo discurso do "fim da história", o decálogo rapidamente ganhou o status de paradigma único do capitalismo triunfante, servindo para enquadrar os governos dos países da periferia a um programa político cujos pilares eram a liberalização da economia mundial ao fluxo de bens, serviços e capitais e a reorientação e remodelagem do Estado como provedor de um marco normativo que garantisse a segurança e a rentabilidade dos negócios privados. ${ }^{87}$ No conjunto, o consenso sintetizava o fim da tolerância de Washington com o nacionalismo econômico pelo mundo afora e o ataque do capital contra o conjunto de direitos sociais e trabalhistas forjados no pós-guerra. $\mathrm{O}$ fato de que o decálogo não tivesse coerência do ponto de vista lógico ${ }^{88}$ em nada diminuiu a sua força normativa.

$\mathrm{Na}$ América Latina, a nova plataforma política rapidamente se internalizou, na medida em que grande parte das principais forças políticas latino-americanas, de praticamente todos os matizes ideológicos e partidos, alinharam-se à ideia de que só havia, então, um único objetivo a perseguir: a construção de uma "economia de mercado" livre e aberta ao capital. E tal objetivo, por sua vez, só poderia ser alcançado por um único caminho: a destruição da soberania nacional em matéria de política econômica e o aniquilamento de todo e qualquer "custo" social e trabalhista que onerasse a rentabilidade dos capitalistas. Nos principais países da região, novas coalizões de poder comprometidas com a plataforma neoliberal passaram a ganhar, em série, eleições presidenciais na virada dos anos oitenta para os noventa. No mesmo período, a negociação com os credores internacionais chegou ao fim e as portas do sistema financeiro internacional se abriram novamente, agora pela via da globalização financeira. Não demorou para que a costura de novas alianças e o acesso à grande onda de liquidez internacional viabilizassem as condições políticas para a geração de planos de estabilização monetária de novo tipo, ${ }^{89}$ estreitamente ligados ao processo de reestruturação econômica neoliberal e, cada vez mais, independentes do governo de plantão.

No Relatório sobre o Desenvolvimento Mundial de 1990, o Banco Mundial sistematizou e prescreveu um modelo de aliviamento compensatório da pobreza que se consolidaria como marco de referência para os Estados clientes, vinculado à neoliberalização do Estado e das políticas sociais. O relatório tinha como premissa a separação entre política social e política econômica. Ancorado na categoria da pobreza absoluta, deixava de lado a questão da concentração de renda e riqueza e propunha uma estratégia dual, que combinava programas focalizados com uma ênfase renovada nas virtudes redentoras do crescimento econômico e do subsequente efeito derrame. O relatório concedia que o ajuste pudesse gerar certos "custos sociais", daí a necessidade de intervençōes focalizadas de caráter (supostamente) compensatório que promovessem o acesso a serviços sociais básicos (sobretudo saúde e educação primárias e planejamento familiar), sob a forma de redes de segurança e programas para a formação de "recursos humanos". Entretanto, segundo o relatório, a criação de oportunidades de elevação da renda dos mais pobres dependia do crescimento econômico, o qual, por sua vez, dependia da implementação das políticas de ajuste estrutural, tidas como as únicas capazes de fazer um uso "mais produtivo do 
bem mais abundante entre os pobres, o trabalho" ${ }^{90}$ Em outras palavras, prescrevia-se um conjunto de políticas direcionadas à liberalização das economias nacionais e à intensificação da exploração da força de trabalho. ${ }^{91}$ Não por acaso, a questão do conflito em torno da produção e da apropriação da riqueza simplesmente não aparecia no texto, o que permitia ao Banco propor que o aliviamento da pobreza dependia tão-somente da distribuição de novos investimentos, e não da redistribuição do estoque de ativos. A rigor, a única inovação significativa em relação aos postulados veiculados pelo Banco nos anos setenta era mesmo o programa radical de liberalização e privatização. De resto, seguia-se basicamente o mesmo discurso, acrescido da confiança renovada no efeito derrame.

Como argumentou Vilas, ${ }^{92}$ com a desregulamentação da economia, a abertura comercial assimétrica, a desregulação financeira e o desmantelamento de grande parte do setor público naqueles anos, os Estados, em particular na América Latina, abandonaram na prática o compromisso político com a promoção da integração e da mobilidade social do conjunto da população. Para institucionalizar as relações de poder que comandavam o ajustamento interno e externo, a ação do Estado foi direcionada para a definição de novos ganhadores e perdedores. Por meio do manejo do câmbio, dos juros e da política tributária, a ação estatal passou a bombear cada vez mais renda para o capital e, em particular, a sua fração financeira. Subordinada ao ajustamento macroeconômico, ganhou impulso a remodelagem da política social, centrada em três mudanças principais. Em primeiro lugar, a política social deixou de ser pensada como um insumo necessário ao investimento privado, como uma dimensão estrutural da acumulação capitalista, e passou a ser vista como gasto. Como consequência, o conceito de "integração social" cedeu lugar ao de "compensação social". Em segundo lugar, em vez de incorporar os estratos mais pobres da população em condiçôes satisfatórias de emprego e renda, a nova política social visava impedir uma deterioração ainda maior de suas condições de vida, assumindo um caráter assistencialista. Em terceiro lugar, a política social foi redefinida como algo transitório, seja porque se supunha que o ajuste macroeconômico produzia crescimento sem inflação a partir do qual viria o gotejamento para baixo dos ganhos do setor mais dinâmico da economia - tornando desnecessária a manutenção certos programas sociais -, seja porque os próprios programas sociais passaram a ter "portas de saída", renovando a sua clientela periodicamente. Subordinada à necessidade de assegurar a governabilidade do ajuste e, portanto, à evolução da conjuntura política, a política social assumiu cada vez mais uma função de "bombeiro", atuando em situações que poderiam se converter em focos de tensão política ou criar insegurança para o livre fluxo de capital e mercadorias.

No mesmo período, a neoliberalização da política social andou junto com a institucionalização da tese de que a eficácia da gestão pública dependia da parceria entre agências estatais e organizações sociais. ${ }^{93}$ A participação da "sociedade civil" na gestão das políticas públicas se tornou um axioma desde então. ${ }^{94}$ Todavia, "sociedade civil” foi tomada como sinônimo de associações voluntárias e ONGs. De modo geral, sindicatos, movimentos populares e organizaçôes camponesas e indígenas ficaram de fora. Convenientemente, o Banco manteve nas sombras a "participação" discreta, mas regular, do setor privado (indústrias, agroindústrias, empreiteiras, bancos e empresas de consultoria) em suas operaçóes. ${ }^{95}$

A incorporação de associações voluntárias e ONGs no desenho, na implementação e, acima de tudo, na gestão de projetos financiados pelo Banco cresceu de modo constante ao longo dos anos oitenta, na esteira da neoliberalização ao sul. De 1980 a 1994, o percentual de projetos que contavam com a cooperação de ONGs aumentou de seis para quase cinquenta por cento. ${ }^{96} \mathrm{Em}$ parte, esse aumento era uma resposta à contestação feita por grandes ONGs internacionais às políticas de ajustamento e aos impactos sociais e ambientais de projetos financiados pelo Banco. Em larga medida, era também uma expressão da permeabilidade crescente entre o campo das ONGs e a rede (pública e privada) de assistência internacional. Segundo cálculos do Banco, a contribuição financeira das ONGs para fins de "desenvolvimento" (saúde, educação, habitação, agricultura etc.) aos países periféricos em 1970 tinha sido inferior a US\$ 9 milhões, mas dezenove anos depois havia alcançado US\$ 6,4 bilhōes, incluindo US\$ 
2,2 bilhōes de fundos oficiais, o que correspondia a doze por cento de toda a assistência internacional, pública (bilateral e multilateral) e privada (filantrópica), para esse fim. ${ }^{97}$

À medida que a institucionalização e a profissionalização se impunham como formas de sobrevivência ante a concorrência cada vez mais acirrada por financiamento e espaço de atuação, inúmeras ONGs passaram a se assemelhar cada vez mais às organizações internacionais empresariais e multilaterais em sua lógica de funcionamento, sua estrutura organizacional e seu modo de operação - ainda que não necessariamente partilhassem os mesmos objetivos. ${ }^{98}$ Ao mesmo tempo, à medida que avançava a reestruturação capitalista neoliberal no sul e, depois de 1989-91, no leste, abria-se um enorme campo de atuação para aquelas ONGs preparadas para desempenhar funções arrancadas do Estado, entre as quais a gestão da pobreza, de forma ultraespecializada e sob a condição de atores terceirizados. ${ }^{99}$

\section{Conclusão}

Historicamente, a carteira de empréstimos do Banco Mundial funcionou como instrumento para fazer circular, internalizar e institucionalizar o produto principal: ideias econômicas e prescrições políticas sobre o que fazer, como fazer, quem deve fazer e para quem em matéria de desenvolvimento capitalista, nas suas mais variadas dimensões. A construção político-intelectual do "combate à pobreza" fez parte dessa trajetória a partir do final dos anos sessenta. Após duas décadas alimentado por empréstimos, assistência técnica a governos, articulaçôes com outras agências de desenvolvimento e milhares de publicaçōes promovidos pelo Banco Mundial, o enfoque orientado à pobreza terminou por impor em âmbito internacional, no bojo dos programas de ajustamento estrutural, uma maneira específica de se pensar e se fazer política social, baseada na separação teórica entre produção da pobreza e produção da riqueza e na noção de mínimos sociais. Não se entende como uma mudança política e intelectual dessa envergadura foi possível se não se tem em conta a atuação financeira e não-financeira do Banco Mundial.

\section{Notas}

${ }^{1} \mathrm{O}$ presente artigo sintetiza argumentos desenvolvidos extensamente em PEREIRA, João Márcio Mendes. O Banco Mundial como ator político, intelectual e financeiro (1944-2008). São Paulo/Rio de Janeiro: Civilização Brasileira, 2010.

${ }^{2}$ Cf. AYRES, Robert. Banking on the poor: the World Bank and world poverty. London: MIT Press, 1983. p. 7.

${ }^{3}$ Cf. McNAMARA, Robert. A essência da segurança. São Paulo: IBRASA, 1968. p. 143.

${ }^{4}$ ROSTOW, Walter W. A estratégia americana. Rio de Janeiro: Zahar, 1965.

${ }^{5}$ Cf. McNAMARA, Robert. A essência da segurança, op. cit., p. 171.

${ }^{6}$ Idem, ibidem, p. 12 e 173.

${ }^{7}$ Cf. GWIN, Catherine. U.S. relations with the World Bank, 1945-1992. In: KAPUR, Devesh et al (eds.). The World Bank: its first half century - Perspectives. Washington DC: Brookings Institution Press, 2, 1997. vol. p. 211.

${ }^{8}$ Idem, ibidem, p. 211-13.

${ }^{9}$ Cf. BURBACH, Roger e FLYNN, Barbara. Agroindústria nas Américas. Rio de Janeiro: Zahar, 1982. p. $72-73$.

${ }^{10}$ McNAMARA, Robert. A imposição do desenvolvimento. In: Cem países, dois bilhões de seres: a dimensão do desenvolvimento. Rio de Janeiro: Fundação Getúlio Vargas, 1974a. p. 5.

${ }^{11}$ Idem, ibidem, p. 4.

${ }^{12}$ Uma das coordenadas intelectuais que guiavam o Banco e todo o mainstream da assistência internacional ao desenvolvimento era a ideia de que a distribuição de renda se concentrava nos estágios iniciais do ciclo econômico e se desconcentrava nos estágios finais, de tal maneira que, após uma fase ascendente e sustentada de crescimento econômico, operar-se-ia o "efeito derrame" (trickle-down), i.e., o gotejamento gradual de renda para os estratos mais baixos da estrutura social. Ver KAPUR, Devesh et al. The World Bank: its first half century. History. Washington DC: Brookings Institution Press, 1997. vol. 1. p. 116-17; STERN, Nicholas e FERREIRA, Francisco. The World Bank as “intellectual actor". In: KAPUR, Devesh et al. (eds.). The World Bank: its first half century - Perspectives, op. cit., p. 530-32. Quanto tempo esse processo duraria e qual a intensidade e o alcance do derrame acabaram se tornando questóes secundárias naquele período frente à própria crença no derrame. 
${ }^{13}$ Cf. KAPUR, Devesh et al. The World Bank: its first half century. History, op. cit., p. 217.

${ }^{14}$ Cf. BANCO MUNDIAL. Annual report. Washington DC: The World Bank, 1968. p. 11.

${ }^{15}$ Cf. McNAMARA, Robert. A imposição do desenvolvimento, op. cit., p. 11.

${ }^{16}$ Cf. TOUSSAINT, Eric. Banco Mundial: el golpe de Estado permanente. Madri: El Viejo Topo, 2006. p. 110-11.

${ }^{17}$ Cf. McNAMARA, Robert. A imposição do desenvolvimento, op. cit., p. 8-9.

${ }^{18}$ Cf. RICH, Bruce. Mortgaging the Earth: the World Bank, environmental impoverishment, and the crisis of development. Boston: Beacon Press, 1994., p. 82-83; KAPUR, Devesh et al. The World Bank, op. cit., p. 220.

${ }^{19}$ Cf. GEORGE, Susan e SABELLI, Fabrizio. La religión del crédito: el Banco Mundial y su imperio secular. 2.ed. Barcelona: Intermón, 1996. p. 57-58.

${ }^{20}$ Cf. MASON, Edward e ASHER, Robert. The World Bank since Bretton Woods. Washington DC: The Brookings Institution, 1973. p. 574.

${ }^{21}$ Cf. KAPUR, Devesh et al. The World Bank, op. cit., p. 399-401.

${ }^{22}$ Idem, ibidem, p. 401.

${ }^{23}$ Ver GOLDMAN, Michael. Imperial nature: the World Bank and struggles for social justice in the age of globalization. New Haven/London: Yale University Press, 2005.

${ }^{24}$ Cf. FINNEMORE, Martha. Redefining development at the World Bank. In: COOPER, Frederick e PACKARD, Randall (eds.). International Development and the Social Sciences. Essays on the history and politics of knowledge. Berkeley: University of California Press, 1997. p. 214-16.

${ }^{25}$ Cf. FINNEMORE, Martha. Redefining development at the World Bank, op. cit., p. 207; KAPUR, Devesh et al. The World Bank, op. cit., p. 247.

${ }^{26}$ Cf. KAPUR, Devesh et al. The World Bank, op. cit., p. 130.

${ }^{27}$ Idem, ibidem, p. 251-52.

${ }^{28}$ Cf. HUNTINGTON, Samuel. A ordem politica nas sociedades em mudança. São Paulo: Editora da USP; Rio de Janeiro: Forense Universitária, 1975. p. 302.

${ }^{29}$ Cf. GOLDMAN, Michael. Imperial nature, op. cit., p. 68-69.

${ }^{30}$ Cf. FINNEMORE, Martha. Redefining development at the World Bank, op. cit., p. 208-09.

${ }^{31}$ Cf. BUSTELO, Pablo. Teorías contemporáneas del desarrollo económico. Madri: Editorial Sintesis, 1999. p. 144.

${ }^{32}$ Cf. AYRES, Robert. Banking on the poor, op. cit., p. 9.

${ }^{33}$ Cf. KAPUR, Devesh et al. The World Bank, op. cit., p. 239-40.

${ }^{34}$ Cf. McNAMARA, Robert. Discurso ante la Junta de Gobernadores. Washington DC: 25-29 de septiembre, 1972 . p. 31.

${ }_{35}$ Cf. McNAMARA, Robert. Discurso ante la Junta de Gobernadores. Nairóbi: 24-28 de septiembre, 1973, p. 27.

${ }^{36}$ Cf. FEDER, Ernest. La pequena revolución verde de McNamara. El proyecto del Banco Mundial para la eliminación del campesinado del Tercer Mundo. In: Comercio Exterior (México), vol. 26, no. 7, julio, p. 793-803, 1976. p. 793-94; GEORGE, Susan. O mercado da fome. Rio de Janeiro: Paz e Terra, 1978, p. 238-39.

${ }^{37}$ Cf. AYRES, Robert. Banking on the poor, op. cit., p. 104.

${ }^{38}$ Idem, ibidem, p. 19.

${ }^{39}$ Cf. CHENERY, Hollis et al. Redistribución con crecimiento. Madrid: Tecnos, 1976. p. 76.

${ }^{40}$ Idem, ibidem, p. 78.

${ }^{41}$ Idem, ibidem.

${ }^{42}$ Cf. ASSMANN, Hugo. El “progresismo conservador” del Banco Mundial. In: (ed.). Banco Mundial: un caso de "progressismo conservador". San José: Departamento Ecuménico de Investigaciones, 1980. p. 11.

${ }^{43}$ Cf. AYRES, Robert. Banking on the poor, op. cit., p. 90.

${ }^{44}$ Cf. McNAMARA, Robert. Discurso ante la Junta de Gobernadores, op. cit., p. 6.

${ }^{45}$ Cf. KAY, Cristóbal. Rural poverty and development strategies in Latin America. In: Journal of Agrarian Change, vol. 6, $\mathrm{n}^{\circ}$ 4, October, p. 455-508, 2006. p. 457.

${ }^{46}$ Cf. GOLDMAN, Michael. Imperial nature, op. cit., p. 77-81; FINNEMORE, Martha. Redefining development at the World Bank, op. cit., p. 208.

${ }^{47}$ Cf. ASSMANN, Hugo. El "progresismo conservador" del Banco Mundial, op. cit., p. 47; PAYER, Cheryl. The World Bank: a critical analysis. New York: Monthly Review Press, 1982. p. 140.

${ }^{48}$ Cf. AYRES, Robert. Banking on the poor, op. cit., p. 154; KAPUR, Devesh et al. The World Bank, op. cit., p. 263. 
${ }^{49}$ McNAMARA, Robert. Discurso anual ante la Junta de Gobernadores. Washington DC: 1-5 de septiembre, 1975. p. 36.

${ }^{50}$ Cf. KAPUR, Devesh et al. The World Bank, op. cit., p. 317-18.

${ }^{51}$ Cf. DAVIS, Mike. Planeta Favela. São Paulo: Boitempo, 2006. p. 80-81.

52 Cf. KAPUR, Devesh et al. The World Bank, op. cit., p. 320.

${ }^{3}$ Cf. DAVIS, Mike. Planeta Favela, op. cit., p. 76-81.

${ }^{54}$ Cf. KAPUR, Devesh et al. The World Bank, op. cit., p. 265-67.

${ }^{55}$ Cf. AYRES, Robert. Banking on the poor, op. cit., p. 85-89.

${ }^{56}$ Cf. KAPUR, Devesh et al. The World Bank, op. cit., p. 265-67.

${ }^{57}$ Cf. STREETEN, Paul et al. Lo primero es lo primero: satisfacer las necesidades básicas en los países en desarrollo. Madrid: Tecnos/Banco Mundial, 1986. p. 95-105.

${ }^{58}$ Cf. McNAMARA, Robert. Discurso ante la Junta de Gobernadores. Washington DC: 30 de septiembre, 1980. p. 34.

${ }^{59}$ Cf. ASSMANN, Hugo. El "progresismo conservador” del Banco Mundial, op. cit., p. 49-50.

${ }^{60}$ Cf. KAPUR, Devesh et al. The World Bank, op. cit., p. 339.

${ }^{61}$ Cf. CAUFIELD, Catherine. Masters of illusion: the World Bank and the poverty of nations. New York: Henry Holt, 1996. p. 97-98; GOLDMAN, Michael. Imperial nature, op. cit., p. 74.

${ }^{62}$ Cf. KAPUR, Devesh et al. The World Bank, op. cit., p. 271.

${ }^{63}$ Sobre o tema consulte-se, em especial, RICH, Bruce. Mortgaging the Earth, op. cit.; GEORGE, Susan e SABELLI, Fabrizio. La religión del crédito, op. cit.; CAUFIELD, Catherine. Masters of illusion, op. cit. e SANAHUJA, José Antonio. Altruismo, mercado y poder: el Banco Mundial y la lucha contra la pobreza. Barcelona: Intermón Oxfam, 2001.

${ }^{64}$ Cf. KAPUR, Devesh et al. The World Bank, op. cit., p. 321-39.

${ }^{65}$ Idem, ibidem, p. 321.

${ }^{66}$ Cf. VELASCO E CRUZ, Sebastião. Trajetórias: capitalismo neoliberal e reformas econômicas nos países da periferia. São Paulo: Editora UNESP, 2007. p. 377.

${ }^{67}$ Cf. KAPUR, Devesh et al. The World Bank, op. cit., p. 273; VELASCO E CRUZ, Sebastiāo. Trajetórias, op. cit., p. 378-80.

${ }^{68}$ Cf. TABB, William. Economic governance in the age of globalization. New York: Columbia University Press, 2004. p. 82-83; BRENNER, Robert. O boom e a bolha: os Estados Unidos na economia mundial. Rio de Janeiro, Record, 2003. p. 67-73; VELASCO E CRUZ, Sebastião. Trajetórias, op. cit., p. 364-65.

${ }^{69}$ Cf. GOWAN, Peter. A roleta global: uma aposta faustiana de Washington para a dominação do mundo. Rio de Janeiro: Record, 2003. p. 45-50; SERRANO, Franklin. Relações de poder e a política macroeconômica americana de Bretton Woods ao padrão dólar flexível. In: FIORI, José Luís (Org.). O poder americano. Petrópolis: Vozes, 2004, p. 190-204.

${ }^{70}$ Cf. VELASCO E CRUZ, Sebastiāo. Trajetórias, op. cit., p. 371.

${ }^{71}$ Cf. KAPUR, Devesh et al. The World Bank, op. cit., p. 321.

${ }^{72}$ Idem, ibidem, p. 323-24.

${ }^{73}$ Idem, ibidem, p. 324.

${ }^{74}$ Cf. BANCO MUNDIAL. Accelerated development in Sub-Saharan Africa: an agenda for action. Washington DC: Oxford University Press, 1981. p. 156-157.

${ }^{75}$ Cf. KAPUR, Devesh et al. The World Bank, op. cit., p. 1227.

${ }^{76}$ Idem, ibidem, p. 548.

${ }_{77}$ Cf. STRANGE, Susan. Dinero loco: el descontrol del sistema financiero global. Buenos Aires: Paidós, 1999. p. 121-22; WOODS, Ngaire. The globalizers: the IMF, the World Bank and their borrowers. Ithaca e Londres: Cornell University Press, 2006. p. 84-94.

${ }^{78}$ Cf. TOUSSAINT, Eric. Banco Mundial, op. cit., p. 185.

${ }^{79}$ Idem, ibidem, p. 193-194.

${ }^{80}$ Cf. STERN, Nicholas e FERREIRA, Francisco. The World Bank as “intellectual actor”, op. cit., p. 560.

${ }^{81}$ Cf. KAPUR, Devesh et al. The World Bank, op. cit., p. 353.

${ }^{82}$ Idem, ibidem, p. 365.

${ }^{83}$ Cf. STAHL, Karin. Política social en América Latina: la privatización de la crisis. In: Nueva Sociedad, no 131, mayo-junio, p. 48-71, 1994. p. 54-58; SANAHUJA, José Antonio. Altruismo, mercado y poder, op. cit., p. 131-33.

${ }^{84}$ Ver CORNIA, G.A. et al. (eds.). Adjustment with a human face. Washington DC: Oxford University Press, 1987.

${ }^{85}$ Cf. KAPUR, Devesh et al. The World Bank, op. cit., p. 353. 
${ }^{86}$ Ver WILLIAMSON, John. What Washington means by policy reform. In: Latin American adjustment: how much has happened. Washington DC: Institute of International Economics, 1990. p. 5-20.

${ }^{87}$ Cf. WADE, Robert Hunter. Japón, el Banco Mundial y el arte del mantenimiento del paradigma: el Milagro del Este Asiático en perspectiva política. Desarrollo Económico, vol. 37, no 147, oct.-dic., 1997. p. 351-87.

${ }^{88} \mathrm{Ver}$ GORE, Charles. The rise and fall of the Washington Consensus as a paradigm for developing countries. World Development, vol. 28, no 5, 2000. p. 789-804.

${ }^{89}$ Ver BATISTA JR., Paulo Nogueira. O Plano Real à luz da experiência mexicana e argentina. Estudos Avançados, vol. 10, no 28, set-dez, 1996. p. 127-97.

${ }^{90}$ BANCO MUNDIAL. Informe sobre el Desarrollo Mundial. Washington DC: Oxford University Press, 1990. p. iii.

${ }^{91}$ Ver BURKETT, Paul. Poverty crisis in the Third World: the contradictions of World Bank policy. Monthly Review, vol. 42, ${ }^{\circ}$ 7, December, 1990. p. 20-31; CAMMACK, Paul. Ataque a los pobres. New Left Review, no 13, jan.-feb., 2002. p. 104-12.

${ }^{2}$ Ver VILAS, Carlos M. La reforma del Estado como cuestión política. Política y Cultura, vol. 8, 1997. p. 147-85; e VILAS, Carlos M. De ambulancias, bomberos y policías: la política social del neoliberalismo (notas para una perspectiva macro). Desarrollo Económico, vol. 36, no 144, jan.-mar., 1997. p. 931-52.

${ }^{33}$ Ver BANCO MUNDIAL. Sub-Saharan Africa: from crisis to sustainable growth. Washington DC: Oxford University Press, 1989; e BANCO MUNDIAL. Informe sobre el Desarrollo Mundial. Washington DC: Oxford University Press, 1991.

${ }^{94}$ Ver CASABURI, Gabriel e TUSSIE, Diana. La sociedad civil y las agendas de los organismos de crédito. In: TUSSIE, Diana (comp.) Luces y sombras de una nueva relación. El Banco Interamericano de Desarrollo, el Banco Mundial y la sociedad civil. Buenos Aires: FLACSO/Temas Grupo Editorial, 2000, p. 15-38; RABOTNIKOF, Nora et al. Los organismos internacionales frente a la sociedad civil: las agendas en juego. In: TUSSIE, Diana (comp.). Luces y sombras de una nueva relación, op. cit., p. 39-72.; NELSON, Paul. Teoría y práctica en la nueva agenda del Banco Mundial. In: TUSSIE, Diana (comp.). Luces y sombras de una nueva relación, op. cit., p. 73-100.

95 Ver HILDYARD, Nicholas. Public risk, private profit: the World Bank and the private sector. The Ecologist, vol. 26, no. 4, 1996. p. 176-79.

${ }^{96}$ Cf. COVEY, Jane. Critical cooperation? Influencing the World Bank through policy dialogue and operational cooperation. In: FOX, Jonathan e BROWN, David (eds.). The struggle for accountability: the World Bank, NGOs and grassroots movements. Cambridge and London: MIT Press, 1998. p. 83.

${ }^{97}$ Cf. BARROS, Flávia. Banco mundial e ONGs ambientalistas internacionais. Ambiente, desenvolvimento, governança global e participação da sociedade civil. Tese de doutorado apresentada ao Programa de Pós-Graduação em Sociologia da Universidade de Brasília. Brasília, 2005. p. 138.

${ }^{98}$ Ver KRUIJT, Dirk. Monopolios de filantropía: el caso de las llamadas "organizaciones no gubernamentales" en América Latina. Polémica, 16, 1992. p. 41-47; SOGGE, David (ed.). Compasión y cálculo: un análisis crítico de la cooperación no gubernamental al desarrollo. Barcelona: Icaria Editorial, 1998; SOGGE, David. Dar y tomar: ¿qué sucede con la ayuda internacional? Barcelona: Icaria Editorial, 2002; e DEZALAY, Yves e GARTH, Bryant. La internacionalización de las luchas por el poder: la competencia entre abogados y economistas por transformar los Estados latinoamericanos. México DF: Instituto de Investigaciones Jurídicas/Universidad Nacional Autónoma de México, 2005.

${ }^{99}$ Cf. WOODS, Ngaire. The globalizers, op. cit., p. 200-01; DAVIS, Mike. Planeta Favela, op. cit., p. 83-84.

\section{Referências bibliográficas}

ASSMANN, Hugo. El “progresismo conservador” del Banco Mundial. In: (ed.). Banco Mundial: un caso de "progresismo conservador”. San José: Departamento Ecuménico de Investigaciones, 1980. p. 9-68.

AYRES, Robert. Banking on the poor: the World Bank and world poverty. London: MIT Press, 1983.

BANCO MUNDIAL. Annual report. Washington DC: The World Bank, 1993. . Informe sobre el Desarrollo Mundial. Washington DC: Oxford University Press, 1991. . Informe sobre el Desarrollo Mundial. Washington DC: Oxford University Press, 1990. . Sub-Saharan Africa: from crisis to sustainable growth. Washington DC: Oxford University Press, 1989. . Accelerated development in Sub-Saharan Africa: an agenda for action. Washington DC: Oxford University Press, 1981.

Informe anual. Washington DC: The World Bank, 1972.

. Annual report. Washington DC: The World Bank, 1968. 
BARROS, Flávia. Banco mundial e ONGs ambientalistas internacionais. Ambiente, desenvolvimento, governança global e participação da sociedade civil. Tese de doutorado apresentada ao Programa de Pós-Graduação em Sociologia da Universidade de Brasília. Brasília, 2005.

BATISTA JR., Paulo Nogueira. O Plano Real à luz da experiência mexicana e argentina. Estudos Avançados, vol. 10, no 28, set-dez, 1996. p. 127-97.

BRENNER, Robert. O boom e a bolha: os Estados Unidos na economia mundial. Rio de Janeiro, Record, 2003. BROWN, Michael Barrat. Africa's choices after thirty years of the World Bank. Boulder: Westview Press, 1995.

BURBACH, Roger e FLYNN, Barbara. Agroindistria nas Américas. Rio de Janeiro: Zahar, 1982.

BURKETT, Paul. Poverty crisis in the Third World: the contradictions of World Bank policy. Monthly Review, vol. 42, no 7, December, 1990. p. 20-31.

BUSTELO, Pablo. Teorías contemporáneas del desarrollo económico. Madri: Editorial Sintesis, 1999.

CAMMACK, Paul. Ataque a los pobres. New Left Review, no 13, jan.-feb., 2002. p. 104-12.

CASABURI, Gabriel e TUSSIE, Diana. La sociedad civil y las agendas de los organismos de crédito. In: TUSSIE, Diana (comp.) Luces y sombras de una nueva relación. El Banco Interamericano de Desarrollo, el Banco Mundial y la sociedad civil. Buenos Aires: FLACSO/Temas Grupo Editorial, 2000. p. 15-38.

CAUFIELD, Catherine. Masters of illusion: the World Bank and the poverty of nations. New York: Henry Holt, 1996.

CHENERY, Hollis et al. Redistribución con crecimiento. Madrid: Tecnos, 1976.

CORNIA, G.A. et al. (eds.). Adjustment with a human face. Washington DC: Oxford University Press, 1987.

COVEY, Jane. Critical cooperation? Influencing the World Bank through policy dialogue and operational cooperation. In: FOX, Jonathan e BROWN, David (eds.). The struggle for accountability: the World Bank, NGOs and grassroots movements. Cambridge and London: MIT Press, 1998. p. 81-120.

DAVIS, Mike. Planeta Favela. São Paulo: Boitempo, 2006.

DEZALAY, Yves e GARTH, Bryant. La internacionalización de las luchas por el poder: la competencia entre abogados y economistas por transformar los Estados latinoamericanos. México DF: Instituto de Investigaciones Jurídicas/Universidad Nacional Autónoma de México, 2005.

FEDER, Ernest. La pequena revolución verde de McNamara. El proyecto del Banco Mundial para la eliminación del campesinado del Tercer Mundo. Comercio Exterior (México), vol. 26, nº 7, julio, 1976. p. 793-803.

FINNEMORE, Martha. Redefining development at the World Bank. In: COOPER, Frederick e PACKARD, Randall (eds.). International Development and the Social Sciences. Essays on the history and politics of knowledge. Berkeley: University of California Press, 1997. p. 203-27.

GEORGE, Susan. O mercado da fome. Rio de Janeiro: Paz e Terra, 1978.

GEORGE, Susan e SABELLI, Fabrizio. La religión del crédito: el Banco Mundial y su imperio secular. 2.ed. Barcelona: Intermón, 1996.

GOLDMAN, Michael. Imperial nature: the World Bank and struggles for social justice in the age of globalization. New Haven/London: Yale University Press, 2005.

GORE, Charles. The rise and fall of the Washington Consensus as a paradigm for developing countries. World Development, vol. 28, no 5, 2000. p. 789-804.

GOWAN, Peter. A roleta global: uma aposta faustiana de Washington para a dominação do mundo. Rio de Janeiro: Record, 2003.

GWIN, Catherine. U.S. relations with the World Bank, 1945-1992. In: KAPUR, Devesh et al (eds.). The World Bank: its first half century - Perspectives. Washington DC: Brookings Institution Press, vol. 2, 1997, p. 195-274.

HILDYARD, Nicholas. Public risk, private profit: the World Bank and the private sector. The Ecologist, vol. 26, no 4, 1996. p. 176-79.

HUNTINGTON, Samuel. A ordem politica nas sociedades em mudança. São Paulo: Editora da USP; Rio de Janeiro: Forense Universitária, 1975.

KAPUR, Devesh et al. The World Bank: its first half century. History. Washington DC: Brookings Institution Press, 1997. vol. 1. 
KAY, Cristóbal. Rural poverty and development strategies in Latin America. Journal of Agrarian Change, vol. 6, no 4, October, 2006. p. 455-508.

KRUIJT, Dirk. Monopolios de filantropía: el caso de las llamadas "organizaciones no gubernamentales" en América Latina. Polémica, 16, 1992. p. 41-47.

MASON, Edward e ASHER, Robert. The World Bank since Bretton Woods. Washington DC: The Brookings Institution, 1973.

McNAMARA, Robert. Discurso ante la Junta de Gobernadores. Washington DC: 30 de septiembre, 1980.

. Discurso anual ante la Junta de Gobernadores. Washington DC: 1-5 de septiembre, 1975.

. O problema da população: mitos e realidades. In: ___ Cem paises, dois bilhôes de seres: a dimensão do desenvolvimento. Rio de Janeiro: Fundação Getúlio Vargas, 1974. p. 17-34.

. A imposição do desenvolvimento. In: . Cem países, dois bilhões de seres: a dimensão do desenvolvimento. Rio de Janeiro: Fundação Getúlio Vargas, 1974a. p. 3-16.

. Discurso ante la Junta de Gobernadores. Nairóbi: 24-28 de septiembre, 1973.

. Discurso ante la Junta de Gobernadores. Washington DC: 25-29 de septiembre, 1972.

A essência da segurança. São Paulo: IBRASA, 1968.

NELSON, Paul. Teoría y práctica en la nueva agenda del Banco Mundial. In: TUSSIE, Diana (comp.). Luces y sombras de una nueva relación. El Banco Interamericano de Desarrollo, el Banco Mundial y la sociedad civil. Buenos Aires: FLACSO/Temas Grupo Editorial, 2000. p. 73-100.

PAYER, Cheryl. The World Bank: a critical analysis. New York: Monthly Review Press, 1982.

. El Banco Mundial y los pequeños agricultores. In: ASSMANN, Hugo (ed.). Banco Mundial: un caso de "progresismo conservador". San José, Departamento Ecuménico de Investigaciones, 1980. p. 135-70.

PEET, Richard et al. La maldita trinidad: el Fondo Monetario Internacional, el Banco Mundial y la Organización Mundial de Comercio. Pamplona: Laetoli, 2004.

PEREIRA, João Márcio Mendes. O Banco Mundial como ator politico, intelectual e financeiro (1944-2008). São Paulo/Rio de Janeiro: Civilização Brasileira, 2010.

RABOTNIKOF, Nora et al. Los organismos internacionales frente a la sociedad civil: las agendas en juego. In: TUSSIE, Diana (comp.). Luces y sombras de una nueva relación. El Banco Interamericano de Desarrollo, el Banco Mundial y la sociedad civil. Buenos Aires: FLACSO/Temas Grupo Editorial, 2000. p. 39-72.

RICH, Bruce. Mortgaging the Earth: the World Bank, environmental impoverishment, and the crisis of development. Boston: Beacon Press, 1994.

ROSTOW, Walter W. A estratégia americana. Rio de Janeiro: Zahar, 1965.

SANAHUJA, José Antonio. Altruismo, mercado y poder: el Banco Mundial y la lucha contra la pobreza. Barcelona: Intermón Oxfam, 2001.

SERRANO, Franklin. Relações de poder e a política macroeconômica americana de Bretton Woods ao padrão dólar flexível. In: FIORI, José Luís (Org.). O poder americano. Petrópolis: Vozes, 2004, p. 190-204.

SOGGE, David. Dar y tomar: ¿qué sucede con la ayuda internacional? Barcelona: Icaria Editorial, 2002.

. (ed.). Compasión y cálculo: un análisis crítico de la cooperación no gubernamental al desarrollo. Barcelona: Icaria Editorial, 1998.

STAHL, Karin. Política social en América Latina: la privatización de la crisis. Nueva Sociedad, $\mathrm{n}^{\circ}$ 131, mayojunio, 1994. p. 48-71.

STERN, Nicholas e FERREIRA, Francisco. The World Bank as “intellectual actor". In: KAPUR, Devesh et al. (eds.). The World Bank: its first half century - Perspectives. Washington DC: Brookings Institution Press, 1997. vol. 2. p. 523-610.

STRANGE, Susan. Dinero loco: el descontrol del sistema financiero global. Buenos Aires: Paidós, 1999.

STREETEN, Paul et al. Lo primero es lo primero: satisfacer las necesidades básicas en los países en desarrollo. Madrid: Tecnos/Banco Mundial, 1986.

TABB, William. Economic governance in the age of globalization. New York: Columbia University Press, 2004. 
TOUSSAINT, Eric. Banco Mundial: el golpe de Estado permanente. Madri: El Viejo Topo, 2006.

VELASCO E CRUZ, Sebastião. Trajetórias: capitalismo neoliberal e reformas econômicas nos países da periferia. São Paulo: Editora UNESP, 2007.

VILAS, Carlos M. La reforma del Estado como cuestión política. Política y Cultura, vol. 8, 1997. p. 147-85.

De ambulancias, bomberos y policías: la política social del neoliberalismo (notas para una perspectiva

macro). Desarrollo Económico, vol. 36, no. 144, jan.-mar., 1997. p. 931-52.

WADE, Robert Hunter. Japón, el Banco Mundial y el arte del mantenimiento del paradigma: el Milagro del Este Asiático en perspectiva política. Desarrollo Económico, vol. 37, no . 147, oct.-dic., 1997. p. 351-87.

WILLIAMSON, John. What Washington means by policy reform. In: Latin American adjustment: how much has happened. Washington DC: Institute of International Economics, 1990. p. 5-20.

WOODS, Ngaire. The globalizers: the IMF, the World Bank and their borrowers. Ithaca e Londres: Cornell University Press, 2006.

\title{
RESUMO
}

Este artigo discute as razōes e os meios pelos quais o Banco Mundial lançou, no final dos anos 1960, o lema do "combate à pobreza". Para isso, relaciona a atuação do Banco a fatores externos, ligados às disputas políticas da Guerra Fria $e$ às provisöes norte-americanas no âmbito do desenvolvimento. O trabalho mostra que instrumentos o Banco utilizou para levar adiante essa divisa; que argumentos lhe deram sustentação, qual direção politica assumiu e que limites enfrentou nos anos 1970. Discute como esse lema foi instrumentalizado pelos programas de ajustamento estrutural implementados durante a década de 1980, culminando na gestação de um novo modelo de política social no início da década de 1990, sintonizado com o neoliberalismo.

Palavras-chave: Banco Mundial; Estados Unidos; assistência externa ao desenvolvimento; pobreza; políticas sociais.

\begin{abstract}
This article discusses the reasons and means through which the World Bank launched the motto of "fight against poverty" in the end of the 1960s. In order to do that, it relates the Bank's actions to external factors, linked to the political disputes of the Cold War and to the North American advancement in the development field. The paper shows which instruments the Bank used to bring forward this motto, which arguments based it, which political guidance it assumed and which limits it faced in the 1970s. It discusses how this motto was used by the structural adjustment programs implemented during the 1980s, culminating in the birth of a new model of social policy in the beginning of the 1990s that was in tune with neoliberalism.

Keywords: World Bank; United States; foreign aid for development; poverty; social policies.
\end{abstract}

